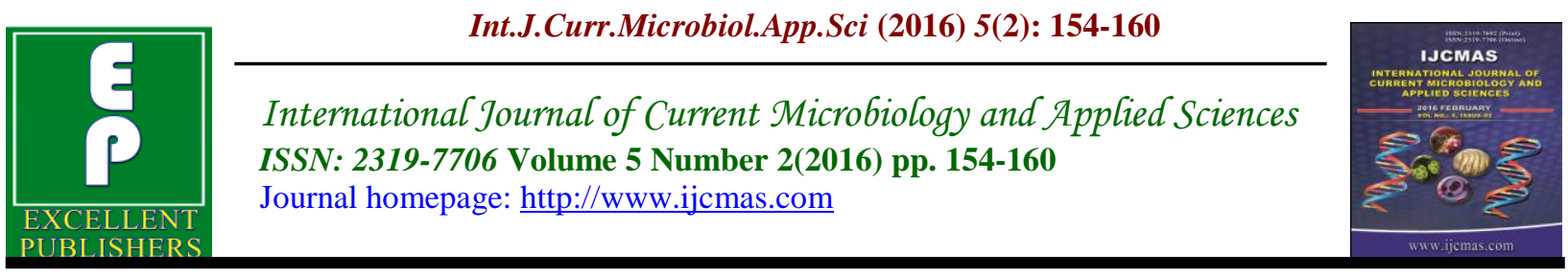

Original Research Article

doi: http://dx.doi.org/10.20546/ijcmas.2016.502.018

\title{
Study of Virulence Genes Cag A and Vac A in Helicobacter pylori Isolated from Mansoura University Hospital Patients by Multiplex PCR
}

\author{
Maysaa El Sayed Zaki ${ }^{1 *}$, Ahmed Elewa ${ }^{1}$, Mahmoud Abdelwahab Ali ${ }^{2}$, Ahmed Shehta ${ }^{2}$ \\ ${ }^{1}$ Clinical Pathology Department, Mansoura Faculty of Medicine, Egypt \\ ${ }^{2}$ Gastroenterology Surgical Center, Mansoura Faculty of Medicine, Egypt \\ *Corresponding author
}

\begin{tabular}{|c|}
\hline Keywords \\
\hline $\begin{array}{l}\text { Virulence Genes } \\
\text { CagA and } \\
\text { VacA, } \\
\text { Helicobacter } \\
\text { pylori, } \\
\text { Multiplex PCR }\end{array}$ \\
\hline Article Info \\
\hline $\begin{array}{l}\text { Accepted: } \\
\text { 12 January } 2015 \\
\text { Available Online: } \\
\text { 10, February } 2016\end{array}$ \\
\hline
\end{tabular}

A B S T R A C T

Helicobacter pylori (H.pylori) is associated with various upper gastrointestinal tract disorders. Virulence genes are cofactors for the pathogenicity of H.pylori. The aims of the present study were to study the prevalence of cagA and vaca genes among H.pylori strains isolated from patients with upper gastrointestinal disorders requiring endoscopic examinations and to relate the presence of these virulence genes to the clinical presentations of those patients. The study included eighty two patients complaining of upper gastrointestinal disorders requiring endoscopic examinations Biopsies were obtained from each subject and specific culture for H.pylori were performed. Multiplex polymerase chain reaction was performed for isolated H.pylori strains to identy the presence of cagA and vaca genes. Their complaints were mainly gastric ulcer $(40.2 \%)$, simple gastritis (32.9\%) and duodenal ulcer $(26.8 \%)$. Culture of H.pylori was positive in $60.9 \%$ of samples. Virulence gene cagA was identified in $62 \%$ and VacA in 58\% of H.pylori isolates. All strains that harbor $v a c A$ had also cagA with two isolates with cagA gene alone. H.pylori was isolated in significant higher percentage $(\mathrm{P}=0007)$ from gastric ulcer (93.9\%) then duodenal ulcer (45.5\%) than simple gastritis $(22.2 \%)$. Both cagA and vacA were significantly $(\mathrm{P}=0.0001)$ associated with gastric ulcer $(51.5 \%$ \& $60.6 \%$ respectively) compared to other clinical finding. From this study we can conclude that $H$.pylori is a common pathogen associated with upper gastrointestinal tract mainly with gastric ulcer. H.pylori strains responsible for gastric ulcer were significantly harboring the caga and vaca virulence genes. These genes may predispose to severe gastric disorders. Extended large scale studies are required to find the pathogenesis of these genes in Egyptian population.

\section{Introduction}

Helicobacter pylori (H.pylori) is a fastidious gram negative bacillus that grows under microaerophilic conditions. It is a widely identified pathogen around the world and defined as an etiological agent of various gastrointestinal disorders that range from simple dyspepsia, gastric ulcer and even gastric carcinoma. WHO has classified $H$. pylori as a class 1 carcinogen (1). The prevalence of $H$. pylori infection varies according to the difference in sanitary conditions and it may exceed $70 \%$ in 
developing countries associated with bad sanitary conditions.

Various factors are claimed to be associated with the degree of the pathogenicity of H.pylori, such as host factors, bacterial virulence genotypes and environmental factors (2). The cagA gene, and the vacuolating cytotoxin gene (vacua) are thought to be implicated in the pathogenicity of $H$. pylori. CagA is encoded by the $\operatorname{cagA}$ gene located at one end of the cag PAI (3). The $\operatorname{cagA}$ gene encodes for a protein that leads a number of cellular changes. It has been reported that $\operatorname{cag} A$ gene is an indicator for the presence of all genes of the cagPAI including cagT, cagM and cagE,. The cagPAI family gene is responsible for type IV secretion system, which delivers CagA positive strains into the cytosol of gastric epithelial cells (4). The $\operatorname{cag} A$ gene is found in high percentage of virulent $H$.pylori strains associated with duodenal ulcer and gastric cancer(4). The profile of cagPAI genes of H.pylori shows great variability worldwide due to insertions or deletions within the cag gene which make its study is necessary in different geographic locations.

The other virulent gene, vacA gene encodes for the vacuolating cytotoxin, the pore forming toxin which leads to gastric epithelial cell injury. The vacuolating activity in host cells varies due to mosaicism of the vacA gene in signal (s) and median (m) regions (5-7).

H.pylori clinical isolates are categorized according to the presence or absence of cagPAI ,affecting the degree of pathogenicity, into type I, associated with severe disease pathology, expresses functional vaca (vacuolating cytotoxin A) and contains the cag (cytotoxin-associated gene) pathogenicity island (cagPAI) and type II lacks cagPAI and had a nontoxic form of vaca and is regarded as less virulent $(8,9)$.

Currently, $\operatorname{cagA}$ genotyping is used as markers for genomic diversity among populations (10).

The aims of the present study were to study the prevalence of $\operatorname{cagA}$ and vaca genes among H.pylori strains isolated from patients with upper gastrointestinal disorders requiring endoscopic examinations and to relate the presence of these virulence genes to the clinical presentations of those patients.

\section{Materials and Methods}

The study included eighty two patients complaining of upper gastrointestinal disorders requiring endoscopic examinations. The patients were recruited from Gastroenterology Surgical Center, Mansoura University, Egypt from March 2014 till October 2015. The study was approved by Mansoura Faculty of medicine medical ethical committee. Each patient signed a written approval to participate in the study.

Each patient was subjected to full medical history taking and clinical examination. Upper gastroduodenal endoscope was performed under standard recommended precautions. Biopsies were obtained from the greater curvature of the stomach about 2 $\mathrm{cm}$ from pylorus and from duodenal ulcer. Each biopsy was transported to the laboratory in sterile container. Biopsies were homogenized and spread over Columbia blood agar supplied with 5\% sheep blood (Oxoid Columbia agar base). Plates were incubated in a microaerophilic atmosphere (oxygen tensions 5-19\% and carbon dioxide tensions $5-10 \%$, by use of gas packs in anaerobic jar (Campy Pak; Becton 
Dickinson) at $37^{\circ} \mathrm{C}$ for 10 days. Identification of $H$. pylori was made by Gram staining of the colonies, lack of aerobic growth on blood agar plates, and testing for the presence of urease, oxidase and catalase (11).

\section{DNA Extraction}

Colonies identified as H.pylori were subjected to DNA extraction by QIAamp DNA Mini Kit (Qiagen, Germany) as manufacturer protocol. The extracted DNA was stored at $-20^{\circ} \mathrm{C}$ until amplification.

\section{Multiples -Polymerase chain Reaction for cagA and VanA genes}

Multiplex PCR was performed to simultaneously detect cagA and VasA genes. Primers sequences used amplifications and the produced bp were summarized in table 1 (12-14).

For amplification process $3 \mu \mathrm{l}$ was added in $25-\mu \mathrm{l}$ volumes containing $2.5 \mathrm{pmol}$ of each primers of VAG and 10 pmol of primers of cag $5 \mathrm{c}-\mathrm{F}$ and cag $3 \mathrm{c}-\mathrm{R}, 0.25 \mathrm{mM}$ of each deoxynucleoside triphosphate, $0.9 \mathrm{U}$ of Taq DNA polymerase and $1.5 \mathrm{mM}$ of $\mathrm{MgCl}_{2}$ in standard PCR buffer (Qiagen).

Products were amplified using Perkin-Elmer 9700 thermal cycler with the following program denaturation for $3 \mathrm{~min}$ at $94^{\circ} \mathrm{C}, 35$ cycles of sequential $1 \mathrm{~min}$ at $94^{\circ} \mathrm{C}-1 \mathrm{~min}$ at $55^{\circ} \mathrm{C}-1 \mathrm{~min}$ at $72^{\circ} \mathrm{C}$, and finally $10 \mathrm{~min}$ at $72^{\circ} \mathrm{C}$.

Detection was performed by gel electrophoresis $2 \%$ for 20 minutes.

\section{Results and Discussion}

The study included eighty two patients. $47.6 \%$ males and $52.4 \%$ females with mean age \pm SD 40.6 \pm 9.5 . Their complaints were mainly gastric ulcer (40.2\%), simple gastritis $(32.9 \%)$ and duodenal ulcer (26.8\%). Culture of H.pylori was positive in $60.9 \%$ of samples. Virulence gene $\operatorname{cagA}$ was identified in $62 \%$ and $V a c A$ in $58 \%$ of H.pylori isolates, table 2

All strains that harbor vacA had also $\operatorname{cag} A$ with two isolates with cagA gene alone, data not shown.

H.pylori was isolated in significant higher percentage $(\mathrm{P}=0007)$ from gastric ulcer $(93.9 \%)$ then duodenal ulcer $(45.5 \%)$ than simple gastritis $(22.2 \%)$, table 3

Both cagA and vacA were significantly $(\mathrm{P}=0.0001)$ associated with gastric ulcer (51.5\% \& 60.6\% respectively) compared to other clinical finding, table 4.

In the present study H.pylori was isolated from $60.9 \%$ of the patients. The patients mean age \pm SD was $40.6 \pm 9.5$ years. This finding is online with previous reports which defined H.pylori prevalence to be from $60 \%$ up to $90 \%$ in adults patients in developing countries. This high infectious rates were attributed to low socioeconomic standards and bad sanitary conditions (15-17)

H.pylori was isolated in significant higher percentage $(\mathrm{P}=0007)$ from gastric ulcer $(93.9 \%)$ then duodenal ulcer $(45.5 \%)$ than simple gastritis (22.2\%). Though colonization with H.pylori is widely reported the association of this pathogen with clinical disorders vary according to multiple factors. Firstly, it remains linked to the distribution of diseases according to age as gastric ulcer usually associated with age over 40 years, duodenal ulcer appears in young age group. Secondly, simple gastritis though associated with H.pylori other conditions could lead to this common 
disorder such as other infectious agents like cytomegalovirus, and autoimmune disorders such as Crohn's disease pernicious anemia, and chronic idiopathic inflammatory chemical damage due to alcohol abuse or nonsteroidal anti-inflammatory drug (NSAID) use. Third factor that is associated with pathogenic pattern of H.pylori is the presence of virulence genes that predispose to its pathogenicity (18-20).

Table.1 Primers Sequences used

\begin{tabular}{|l|l|l|}
\hline Gene & Primer Sequence & bp \\
\hline vacA s1/vacA s2 & $\begin{array}{l}\text { 5'-ATGGAAATACAACAAACACAC-3' } \\
\text { 5'-CTGCTTGAATGCGCCAAAC-3' }\end{array}$ & 259 \\
\hline $\begin{array}{l}\text { vacA m1/vacA } \\
\mathrm{m} 2\end{array}$ & $\begin{array}{l}\text { 5'-CAATCTGTCCAATCAAGCGAG-3 } \\
\text { 5'-GCGTCAAAATAATTCCAAGG-3' }\end{array}$ & 567 \\
\hline cagA & $\begin{array}{l}\text { 5'-GTTGATAACGCTGTCGCTTC-3 } \\
\text { 5'-GGGTTGTATGATATTTTCCATAA-3'" }\end{array}$ & 350 \\
\hline
\end{tabular}

Table.2 Demographic, Clinical and Laboratory Data of Patients

\begin{tabular}{|l|l|}
\hline Data & \\
\hline Age (mean \pm SD) & $40.6 \pm 9.5$ \\
\hline $\begin{array}{l}\text { Sex } \\
\text { female }\end{array}$ & $39(47.6 \%)$ \\
\hline Finding & $43(52 . .4 \%)$ \\
Simple gastritis & \\
Gastric ulcer & $27(32.9 \%)$ \\
Dudenal ulcer & $33((40.2 \%)$ \\
\hline $\begin{array}{l}\text { Culture positive } \\
\text { Genotypes } \\
\text { CagA } \\
\text { VacA }\end{array}$ & $22(26.8 \%)$ \\
\hline
\end{tabular}

Table.3 Relation of H.pylori Culture to Clinical Finding

\begin{tabular}{|l|l|l|l|}
\hline Culture & $\begin{array}{l}\text { Simple Gastritis } \\
(\mathrm{n}=27)\end{array}$ & $\begin{array}{l}\text { Gastric ulcer } \\
(\mathrm{n}=33)\end{array}$ & $\begin{array}{l}\text { Duodenal ulcer } \\
(\mathrm{n}=22)\end{array}$ \\
\hline Positive Culture & $6(22.2 \%)$ & $31(93.9 \%)$ & $10(45.5 \%)$ \\
\hline Negative Culture & $21(77.8 \%)$ & $2(6.1 \%)$ & $12(54.5 \%)$ \\
\hline
\end{tabular}
$\mathrm{P}=0.0007$ 
Table.4 Distribution of CagA and VacA in Relation to Clinical Finding

\begin{tabular}{|l|l|l|l|l|}
\hline & $\begin{array}{l}\text { Dysprsia } \\
(\mathrm{n}=27)\end{array}$ & $\begin{array}{l}\text { gastric ulcer } \\
(\mathrm{n}=33)\end{array}$ & $\begin{array}{l}\text { Dodenal ulcer } \\
(\mathrm{n}=22)\end{array}$ & \\
\hline cagA & $6(22.2 \%)$ & $17(51.5 \%)$ & $8(36.4 \%)$ & .000 \\
\hline vacA & $4(14.8 \%)$ & $20(60.6 \%)$ & $5(22.7 \%)$ & .000 \\
\hline
\end{tabular}

Virulence genes of H.pylori are implicated in epithelium damage of gastric mucosa leading to gastric atrophy that can progress later on to gastric carcinoma. So, it is important to identify patients who harbor these pathogenic strains to properly interfere to prevent this progression (20).

We studied two virulent genes in H.pylori strains isolated from patients namely vacA and $\operatorname{cag} A$ genes. $C a g A$ gene was identified in $62 \%$ and vacA in $58 \%$ of H.pylori isolates. Similar results were obtained from different localities in Egypt (7, amen et al., 2013). The range of distribution of cagA genes varies between $17 \%$ up to $100 \%$ in different geographical regions $(21,22)$.

As regards the presence of virulence genes association with clinical finding,both cagA and vacA were significantly $(\mathrm{P}=0.0001)$ associated with gastric ulcer $(51.5 \%$ \& $60.6 \%$ respectively) compared to other clinical findings.. This finding is contradictory to that reported previously by Amer et al., (2013) (21) from one Egyptian study. However, other studies demonstrating a higher risk for development of peptic ulcer disease upon gastric infection with $H$. pylori strains containing virulence genes (23).

Virulence genes vaca and caga genes are well known virulence factors in H.pylori being responsible for production of two different toxins that affect the epithelium of gastric mucosa and alter immune response resulting in severe gastric disease (24). In vitro study has demonstrated that complete absence $\operatorname{cag}$ PAI was associated with lower production of interleukin $8 . \quad \mathrm{IL}-8$ is multifunctional. In addition to its potent chemotactic activity, it can induce proliferation and migration of cancer cells. In this review, we focus on recent insights into the mechanisms of IL-8 signaling associated with gastric cancer. So, gastric colonization with $\operatorname{cagA}$

Istrains is claimed to be a risk factor for severe gastric and duodenal diseases (25).

From this study we can conclude that H.pylori is a common pathogen associated with upper gastrointestinal tract mainly with gastric ulcer. H.pylori strains responsible for gastric ulcer were significantly harboring the caga and vaca virulence genes. These genes may predispose to severe gastric disorders. Extended large scale studies are required to find the pathogenesis of these genes in Egyptian population.

\section{References}

1.An international association between Helicobacter pylori infection and gastric cancer. The EUROGAST Study Group. Lancet. 1993; 341: 1359-1362.

2.Zabaleta J1. Multifactorial etiology of gastric cancer. Methods Mol Biol. 2012; 863: 411-435.

3.Asahi M, Azuma $\mathrm{T}$, Ito $\mathrm{S}$, et al. Helicobacter pylori CagA protein can be tyrosine phosphorylated in gastric epithelial cells. J ExpMed; (2000): 191: 593-602.

4.Viala J, Chaput C, Boneca IG, et al. Nod1 
responds to peptidoglycan delivered by the Helicobacter pylori cag pathogenicity island. Nat Immunol(2004): 5: 1166-1174.

5.Chattopadhyay S, Datta S, Chowdhury A, Chowdhury S, Mukhopadhyay AK, Rajendran K, et al. Virulence genes in Helicobacter pylori strains from West Bengal residents with overt $\mathrm{H}$. pylori-associated disease and healthy volunteers. J Clin Microbiol. 2002; 40: 2622- 2625.

6.Chattopadhyay S, Patra R, Ramamurthy T, Chowdhury A, Santra A, Dhali GK, $B$ et al. Multiplex PCR assay for rapid detection and genotyping of Helicobacter pylori directly from biopsy specimens. J Clin Microbiol. 2004; 42: 2821-2824.

7.Essawi T, Hammoudeh W, Sabri I, Sweidan W, Farraj MA. Determination of Helicobacter pylori Virulence Genes in Gastric Biopsies by PCR. ISRN Gastroenterol. 2013; 2013: 606258.

8.Censini S, Lange C, Xiang Z, et al. (1996): cag, apathogenicity island of Helicobacter pylori, encodes type Ispecific and disease-associated virulence factors. Proc Natl Acad Sci; 93: 14648-14653.

9.Backert S, Schwarz T, Miehlke S, et al. (2004): Functional analysis of the cag pathogenicity island in Helicobacter pylori isolates from patients with gastritis, peptic ulcer and gastric cancer. Infect Immun; 72: 1043-1056.

10.Linz B, Balloux F, Moodley Y, et al. (2007): An African origin for the intimate association between humans and Helicobacter pylori. Nature; 445: 915-918.

11.Logan, R.P. and Walker, M.M. (2001): $\mathrm{ABC}$ of the upper gastrointestinal tract: Epidemiology and diagnosis of
Helicobacter pylori infection. BMJ. 323 (7318) : 920-2.

12.Chattopadhyay S,Patra R, Ramamurthy T.,Chowdhury A, Santra A, . Dhali G. K, Bhattacharya S. K.,Berg D E., Nair G. B . Mukhopadhyay A K Multiplex PCR Assay for Rapid Detection and Genotyping of Helicobacter pylori Directly from Biopsy Specimens. J Clin Microbiol. 2004 Jun; 42(6): 2821-2824.

13.Atherton, J. C., P. Cao, R. M. J. Peek, M. K. Tummuru, M. J. Blaser, and T. L. Cover. 1995. Mosaicism in vacuolating cytotoxin alleles of Helicobacter pylori: association of specific vacA types with cytotoxin production and peptic ulceration. J. Biol. Chem. 270:17771-17777.

14.Atherton, J. C., T. L Cover, R. J. Twells, M. R. Morales, C. J. Hawkey, and M. J. Blaser. 1999. Simple and accurate PCR-based system for typing vacuolating cytotoxin alleles of Helicobacter pylori. J. Clin. Microbiol. 37:2979-2982.

15.Megraud F. Epidemiology of Helicobacter pylori infection. In: Rathbone BJ, Heatley RV, editors. Helicobacter pylori and gastrointestinal disease. Oxford: Blackwell Scientific; 1992. pp. 10723.

16.Bardhan PK. Epidemiological features of Helicobacter pylori infection in developing countries. Clin Infect Dis. 1997;25:973-8.

17.Cheng H, Hu F, Zhang L, Yang G, Ma J, $\mathrm{Hu}$ J, et al. Prevalence of Helicobacter pylori infection and identification of risk factors in rural and urban Beijing, China. Helicobacter. 2009;14:128-33

18.Kuipers, E. J., J. C. Thijs, and H. P. Festen. 1995. The prevalence of Helicobacter pylori in peptic ulcer 
disease. Aliment. Pharmacol. Ther. 9(Suppl. 2):59-69.

19.Nomura, A., G. N. Stemmermann, P. H. Chyou, G. I. Perez-Perez, and M. J. Blaser. 1994. Helicobacter pylori infection and the risk for duodenal and gastric ulceration. Ann. Intern. Med. 120:977-981

20.Shetty V, Ballal $\mathrm{M}$, Lingadakai $\mathrm{R}$ and Mukhopadhyay A. Determination of Helicobacter pylori Virulence Genes in Clinical Isolates of Symptomatic Patients from South Coastal Region of Karnataka - A Preliminary Work. Austin J Gastroenterol. 2015;2(1): 1031.

21.FA. Amer1, R H. El-Sokkary1, M Elahmady1, $\mathrm{T}$ Gheith1, $\mathrm{E} \quad \mathrm{H}$ Abdelbary2, Y Elnagar3, W M Abdalla4 Helicobacter pylori genotypes among patients in a university hospital in Egypt: identifying the determinants of disease severity. JMID , 2015,2 (1) -

22.Hussein NR. Helicobacter pylori and gastric cancer in the Middle East: A new enigma? World J Gastroenterol 2010;16:3226-3234.

23.Yakoob J, Abid S, Abbas $\mathrm{Z}$ et al. Distribution of Helicobacter pylori virulence markers in patients with gastroduodenal diseases in Pakistan. BMC Gastroenterology 2009;9:8794.

24.Marc Roger Couturier. The Evolving Challenges of Helicobacter pylori Disease, Diagnostics, and Treatment, Part 1. Clinical Microbiology Newsletter. 2013; $35: 19-24$.

25.Jang $\mathrm{S}$, Jones $\mathrm{KR}$, Olsen $\mathrm{CH}$, et al. Epidemiological Link between Gastric Disease and Polymorphisms in VacA and CagA. J Clin Microbiol 2010;48:559-567.

26.Kusters JG, van Vliet AHM, Kuipers EJ. Pathogenesis of Helicobacter pylori Infection. Clinical Microbiology Reviews. 2006;19(3):449-490. doi:10.1128/CMR.00054-05.

\section{How to cite this article:}

Maysaa El Sayed Zaki, Ahmed Elewa, Mahmoud Abdelwahab Ali, Ahmed Shehta. 2016. Study of Virulence Genes Cag A and Vac A in Helicobacter pylori Isolated from Mansoura University Hospital Patients by Multiplex PCR. Int.J.Curr.Microbiol.App.Sci. 5(2): 154-160. doi: http://dx.doi.org/10.20546/ijcmas.2016.502.018 